\title{
Optimal Thermal Insulation Thickness in Isolated Air-Conditioned Buildings and Economic Analysis
}

\author{
Mousa M. Mohamed \\ Department of Mechanical Power Engineering, Faculty of Engineering, Menoufia University, Shebin El Kom, Egypt \\ Email: mousamohamed@yahoo.com
}

How to cite this paper: Mohamed, M.M. (2020) Optimal Thermal Insulation Thickness in Isolated Air-Conditioned Buildings and Economic Analysis. Journal of Electronics Cooling and Thermal Control, 9, 23-45.

https://doi.org/10.4236/jectc.2020.92002

Received: May 14, 2020

Accepted: June 16, 2020

Published: June 19, 2020

Copyright $\odot 2020$ by author(s) and Scientific Research Publishing Inc. This work is licensed under the Creative Commons Attribution International License (CC BY 4.0).

http://creativecommons.org/licenses/by/4.0/

\begin{abstract}
The removal building heat load and electrical power consumption by air conditioning system are proportional to the outside conditions and solar radiation intensity. Building construction materials has substantial effects on the transmission heat through outer walls, ceiling and glazing windows. Good thermal isolation for buildings is important to reduce the transmitted heat and consumed power. The buildings models are constructed from common materials with $0-16 \mathrm{~cm}$ of thermal insulation thickness in the outer walls and ceilings, and double-layers glazing windows. The building heat loads were calculated for two types of walls and ceiling with and without thermal insulation. The cooling load temperature difference method, CLTD, was used to estimate the building heat load during a 24-hour each day throughout spring, summer, autumn and winter seasons. The annual cooling degree-day, $C D D$ was used to estimate the optimal thermal insulation thickness and payback period with including the solar radiation effect on the outer walls surfaces. The average saved energy percentage in summer, spring, autumn and winter are $35.5 \%, 32.8 \%, 33.2 \%$ and $30.7 \%$ respectively, and average yearly saved energy is about of $33.5 \%$. The optimal thermal insulation thickness was obtained between $7-12 \mathrm{~cm}$ and payback period of $20-30$ month for some Egyptian Cities according to the Latitude and annual degree-days.
\end{abstract}

\section{Keywords}

Building Heat Load, Cooling Load Temperature Difference, Energy Saving, Power Consumption, Annual Cooling Degree-Day, Optimal Thermal Insulation Thickness, Payback Period

\section{Introduction}

The buildings heat load is proportional to the transmission heat through outside 
walls, ceiling, and glazing windows. The transmission heat load is added to the internal building heat load in summer season and subtracted from it in winter season. The thermal insulation is an effective tool to achieve the minimum heat transmission through walls. The transmission heat is a function of the thermal resistance of composite wall materials which actually are related to the thermal insulation thickness. Obviously, the increasing of thermal insulation thickness will increase the investment cost, but reduce the electrical power consumption. The problem is how we can compromise between the investment of insulation cost and the running cost of electrical power consumption.

Recently, many authors have studied the effect of thermal insulation thickness on the building transmission heat load and power consumption. The degree-day method is one of the well-known and the simplest methods used in the Heating, Ventilating and Air-Conditioning industry to estimate heating and cooling energy requirements. The yearly heating and cooling degree-hours are given both in tabular form and as counter maps [1] [2] [3]. Unsteady heat transfer throughout a composite wall exposed to explicit solar radiation and sinusoidal ambient temperature with Laplace s-domain is presented [4]. The solution is transformed back to the time domain using a series formula to provide an efficient alternative to a purely numerical treatment. A systematic approach for optimization of thermal insulation thickness is developed based on the life cycle cost analysis. Energy saving and payback periods are possible for rock wool and polystyrene insulation depending on the type of walls structure [5].

The effect of external roof color surface with periodic heat flow through a homogeneous flat solid concrete slab by solving the heat conduction equation was studied analytically [6]. They concluded that the influence of exterior color on reducing cooling loads has a minor effect when the concrete thickness from $15 \mathrm{~cm}$ and more. An experimental correlation between thermal conductivity and insulation thickness of certain insulation materials was presented to estimate the optimum thermal insulation thickness just by knowing the thermal conductivity [7]. An analytical investigation based on Complex Finite Fourier Transform to estimate the yearly building heat loads for two types of insulation materials and two typical wall structures [8]. They concluded that the most profitable case is the sandwich wall made of stone and brick with expanded polystyrene. The optimum insulation thickness of $5.7 \mathrm{~cm}$ provides energy savings of $58 \%$ and payback period of 37 months. Technical and economic optimal thermal insulation thickness of an external wall made from bricks was presented [9]. The data obtained from the mathematical model are illustrated in graphs to show the optimum thickness and minimum payback period.

A coupled heat and moisture transfer model is used to estimate the insulation thickness, lifecycle saving, and payback period [10]. They concluded that the lifecycle total cost of exterior wall using Expanded Polystyrene, XPS is lower than that using Extruded polystyrene, EPS insulation. The optimum thickness of XPS is between 0.053 and $0.069 \mathrm{~m}$, and the optimum thickness of EPS is between 0.081 
and $0.105 \mathrm{~m}$, and the payback period varies from 23 to 31 months. A numerical solution of transient heat transfer through multilayer walls subjected to the average outdoor temperature and solar radiation was conducted [11] [12]. They concluded that the wall orientation had a significant effect on the optimum insulation thickness and energy savings. An economic model based on life-cycle cost analysis was used [13] [14]. They found that the optimum thermal insulation thickness increased with increasing the heating and cooling energy requirements, the lifetime of the building, the inflation rate, energy costs and thermal conductivity of insulation. Also, the insulation thickness decreased with increasing the discount rate, the insulation material cost, the total wall resistance, the coefficient of performance and the solar radiation. Recent studies are focused on energy saving in air-conditioned buildings according to the walls materials, insulation thickness, total life-cycle cost and walls orientation [15] [16] [17] [18]. Unsteady heat transmission through a composite wall was considered as one-dimensional problem to improve the accuracy of the optimal insulation thickness by using real meteorological data [19]. In the previous studies, there are very limited studies investigate the effect of solar radiation on the thermal insulation thickness and energy saving through 24 hours a day during four seasons, spring, summer, autumn and winter.

The objective of the present study is to investigate the thermal insulation thickness and energy saving in air-conditioned buildings. The analysis was conducted using expanded polystyrene thermal insulation in two types of outer wall surfaces with and without subjected to solar radiation. The hourly building heat load and power consumption with Cooling Load Temperature Deference, CLTD, method are estimated at various thermal insulation thickness and outside atmospheric conditions. The annual cooling degree-day, $C D D$, with including the solar radiation on the outer walls is presented to obtain the optimal insulation thickness and payback period.

\section{Methodology}

\subsection{Residential Building Model}

The transmission heat load is calculated according to the building construction materials. The building model we used was residential buildings or hotels with size of $18 \times 18 \times 3 \mathrm{~m}$ as illustrated in [20] [21]. The building was constructed from a common construction material and a single layer glazing windows with wooden doors as shown in Figure 1(a). The building outer wall models, A and B are shown in Figure $1(\mathrm{~b})$. The building and walls model $\mathrm{A}$ is constructed from common materials; hollow bricks, heavy concrete, single layer clear glazing windows with aluminum frame, medium textile curtain, and wooden doors. The building and walls model B is the same as model A of construction materials in addition to $0-12 \mathrm{~cm}$ thermal insulation thickness of expanded polystyrene with thermal conductivity of $0.039 \mathrm{~W} /(\mathrm{m} \cdot \mathrm{K})$ in outer walls, and ceiling. The glazing windows are double layers clear glass with air gab of $1-3 \mathrm{~cm}$ [21]. 


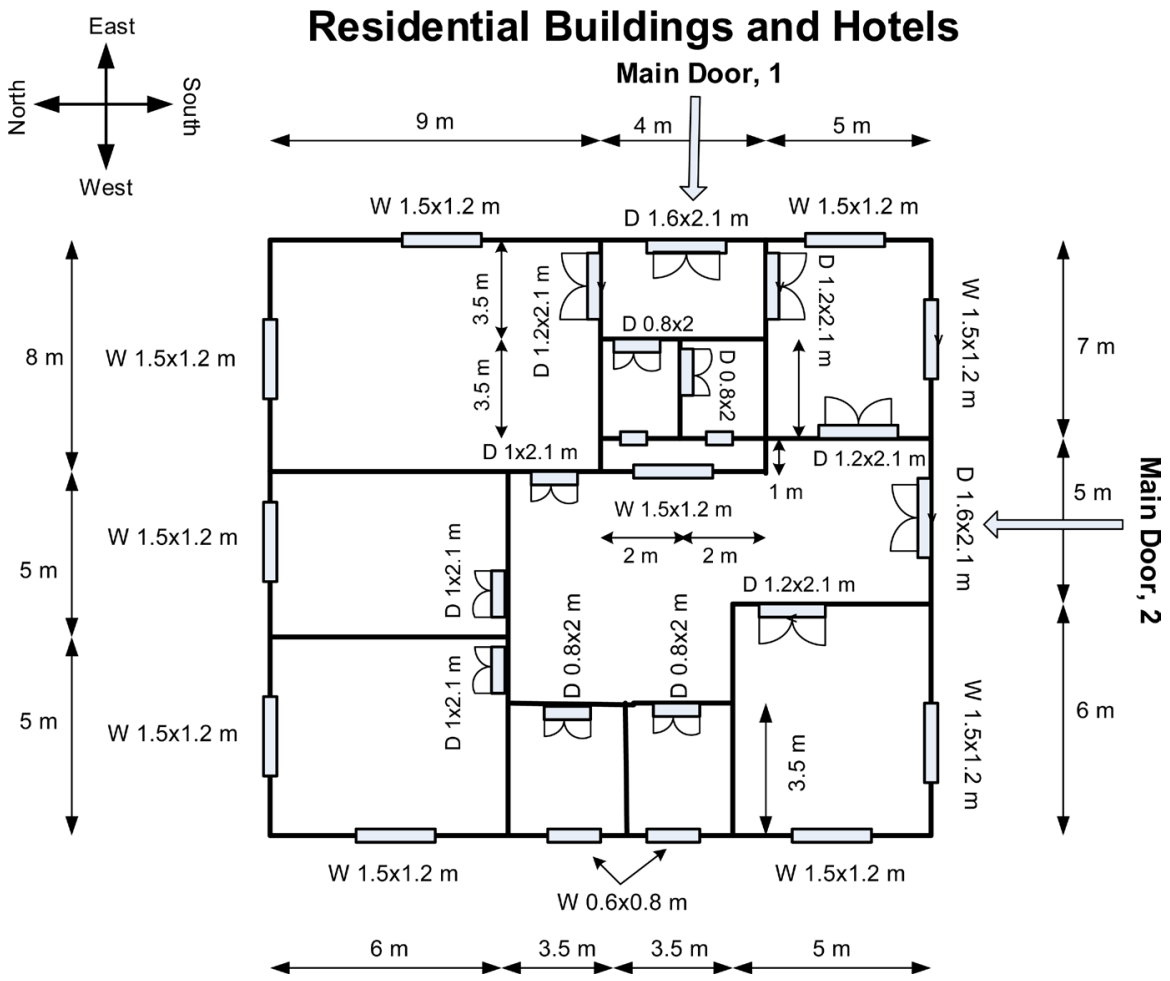

(a)

Model B

Model A
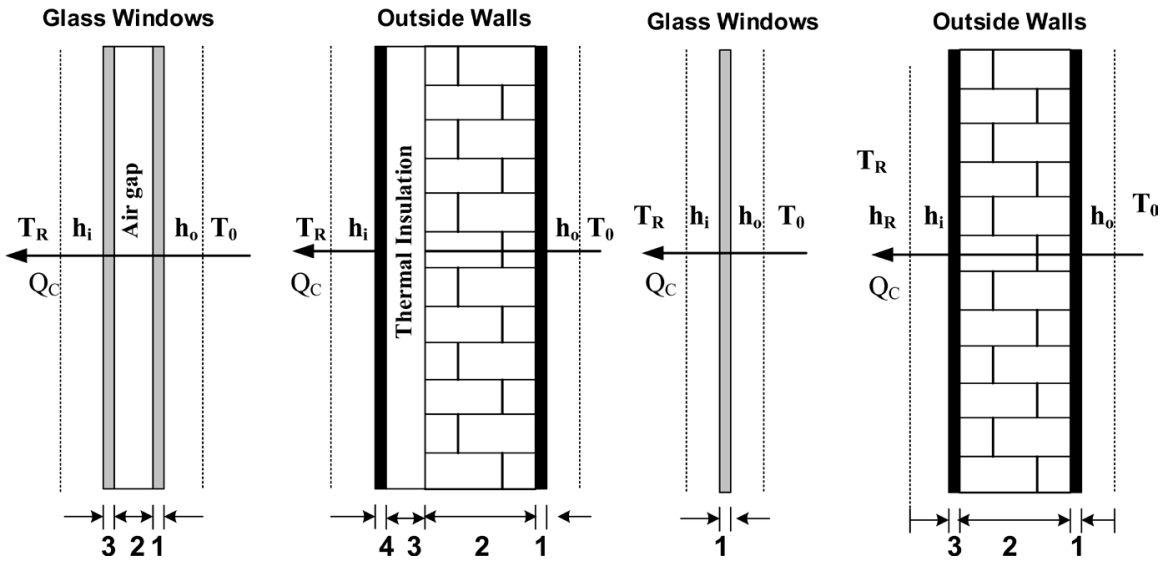

(b)

Figure 1. (a) Residential building layout; (b) Composite wall and glass window model A and $\mathrm{B}$.

The building heat load is the amount of heat removed or added to the internal heat load to maintain the thermal comfort inside the building. The building heat load is two main parts. The first part is the sensible heat load which is a function of dry bulb temperature difference between outside and inside air condition, and radiation heat gain through glazing windows. The second part is the latent heat load which is a function of moisture transfer and vapor content inside the conditioned space. The building heat load in summer is the summation of internal and external heat loads. But, in winter is the difference between the internal and 
external heat loads. The building heat load was calculated using the Cooling Load Temperature Difference, CLTD method as illustrated in [22]. A computer program is prepared and tested under the constraints of the building orientation and north latitude and longitude. The data needed according to the CLTD method for outside air conditions and building construction materials are inserted as a subroutine to get the hourly building heat load at four seasons, spring, summer, autumn and winter.

\subsection{Heat Transmission through Outer Surfaces Walls}

The outer walls surfaces are subjected to instantaneous temperature $T_{o}(t)$ and solar radiation $I(t)$. The inner faces of walls come in contact with the indoor air which maintained at a fixed temperature of $T_{i}, 24^{\circ} \mathrm{C}$ to have a better thermal comfort. The one dimensional transient heat conduction model with constant thermal conductivity, density and heat capacity is used for this problem as follows:

$$
\frac{\partial T(x, t)}{\partial t}=\frac{k}{\rho C_{p}} \frac{\partial^{2} T(x, t)}{\partial x^{2}}
$$

where $k$ is the thermal conductivity, $\rho$ is the density and $C_{p}$ is the specific heat of the wall material. To solve this problem, two boundary conditions and one initial condition are required. On both sides of the wall, convection boundary conditions are present. On the inner surface, at constant inside convection heat transfer coefficient is:

$$
-\left.k \frac{\partial T(x, t)}{\partial x}\right|_{x=L}=h_{i}\left(T_{x=L}(t)-T_{i}\right)
$$

Whereas on the outdoor surface of the wall, the boundary condition at constant outside convection heat transfer coefficient can be written as:

$$
-\left.k \frac{\partial T(x, t)}{\partial x}\right|_{x=0}=h_{o}\left(T_{o}(t)-T_{x=0}(t)\right)
$$

where, $h_{o}, h_{i}$ are the film convection heat transfer coefficient of outside and inside walls of building, and their values are $h_{o}=22 \mathrm{~W} / \mathrm{m}^{2} \cdot \mathrm{K}$ and $h_{i}=9 \mathrm{~W} / \mathrm{m}^{2} \cdot \mathrm{K}$ [23] [24]. $T_{i}$ is the indoor air temperature; $T_{o}(t)$ is the outdoor air temperature; $T_{x=0}(t)$ is the wall inner surface temperature, and $T_{x=L}(t)$ is the wall outer surface temperature, respectively.

The steady-state solution of the problem at constant inside room temperature, constant inside and outside film convection heat transfer coefficient is taken. The function of outdoor temperature which is assumed to show sinusoidal variations during a 24-hour period, the instantaneous transmission heat transfer rate through walls from outside to inside is defined as,

$$
Q_{\text {trans }}(t)=A U\left(T_{o}(t)-T_{i}\right)
$$

where, $T_{o}(t)$ is the instantaneous outside temperature, and $T_{i}$ is the indoor 
temperature. In steady state condition, the temperature difference is replaced by $\Delta T$ as mention in [20] according to Cooling Load Temperature Deference, $C L T D$ method and which is defined as,

$$
\Delta T=(C L T D+L M) \cdot K+\left(25.5-T_{i}\right)+\left(T_{o}(h)-29.4\right)
$$

where, $C L T D$ is the correction temperature difference according to latitude and surface orientation, $L M$ is the correction factor of latitude, $K$ is the color factor, $T_{o}(h)$ is hourly outside temperature, $A$ is the outer walls area, and $U$ is the overall heat transfer coefficient which is defined as,

$$
\frac{1}{U}=\frac{1}{h_{i}}+\left.\sum \frac{\Delta x}{k}\right|_{\text {materials }}+\left.\frac{\Delta x}{k}\right|_{\text {insulation }}+\frac{1}{h_{o}}
$$

To investigate the effect of thermal insulation thickness on the building heat load, we assumed all parameters are constant except thermal insulation thickness. The thermal resistance of composite wall can be written in a linear form as,

$$
R=\frac{1}{U}=C_{1}+\left.C_{2} \Delta x\right|_{\text {insulation }}
$$

where $C_{1}$ and $C_{2}$ are constants, and the hourly heat transfer through the walls can be defined as,

$$
Q_{\text {trans }}=U A \Delta T
$$

In the numerical calculation, some assumptions were made. The thickness of the composite wall is small compared to other dimensions. So one-dimensional temperature variation is assumed. The layers are in good contact; hence the interfacial resistance is negligible. There is no heat generation. The variation of the wall materials thermal properties is negligible. The convection heat transfer coefficient and room temperature is constant.

\subsection{Hourly outside Air Temperature and Relative Humidity}

The hourly outside air conditions of dry bulb temperature and relative humidity are used in this analysis as illustrated in [20] [21]. The average data of dry bulb temperature, and relative humidity at latitude of $21.42^{\circ} \mathrm{N}$ and longitude of $39.83^{\circ} \mathrm{E}$, Makkah City, Saudi Arabia, for each season are illustrated in Figure 2 and Figure 3. The outside dry bulb temperature is continuously increased from sunrise to maximum value at 3:00 PM and decreased again to minimum value at night as shown in Figure 2. Opposite trend of dry bulb temperature, the relative humidity, which decreased from sunrise to minimum value at 3:00 PM and increased again to maximum value at night as shown in Figure 3.

\section{Building Heat Loads}

The total building heat loads in four season, summer, spring, autumn, and winter with constant internal heat loads are calculated at various thermal insulation thickness, $\Delta x$ of $0-12 \mathrm{~cm}$. The results of total building heat loads in four season are shown in Figures 4-7. We can see a clear and systematic effect of thermal 


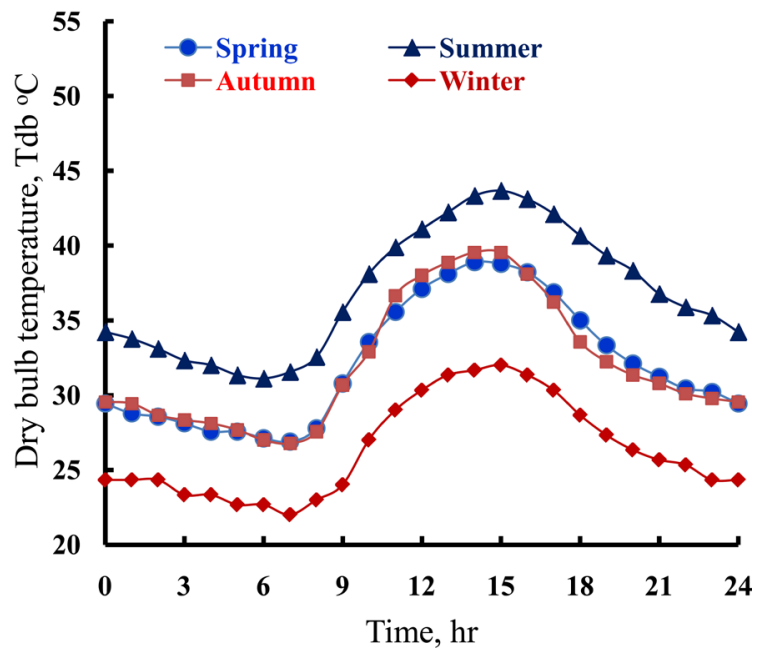

Figure 2. Dry bulb temperature at lat. $21.42^{\circ} \mathrm{N}$ and long. $39.83^{\circ} \mathrm{E}$ [21].

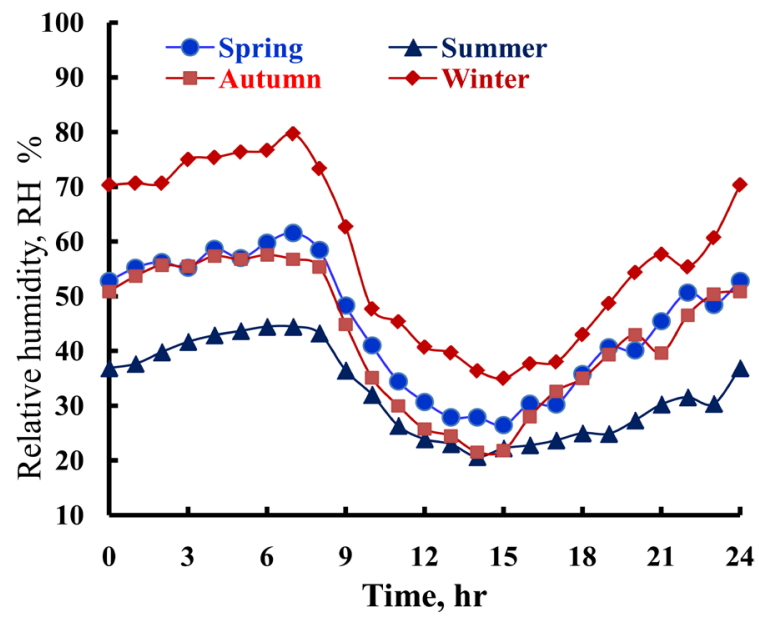

Figure 3. Relative humidity at lat. $21.42^{\circ} \mathrm{N}$ and long. $39.83^{\circ} \mathrm{E}$ [21].

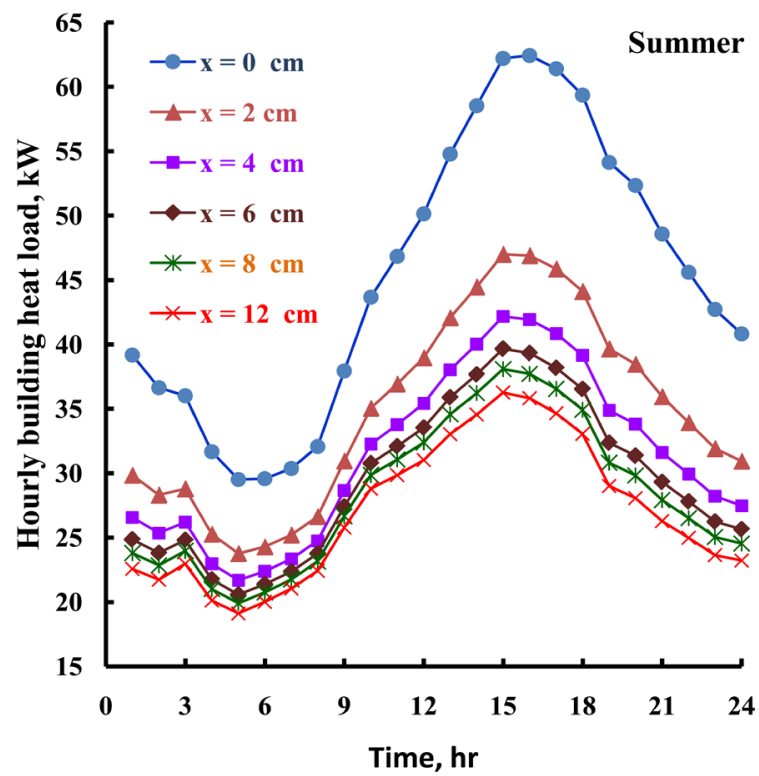

Figure 4. Building heat load in summer. 


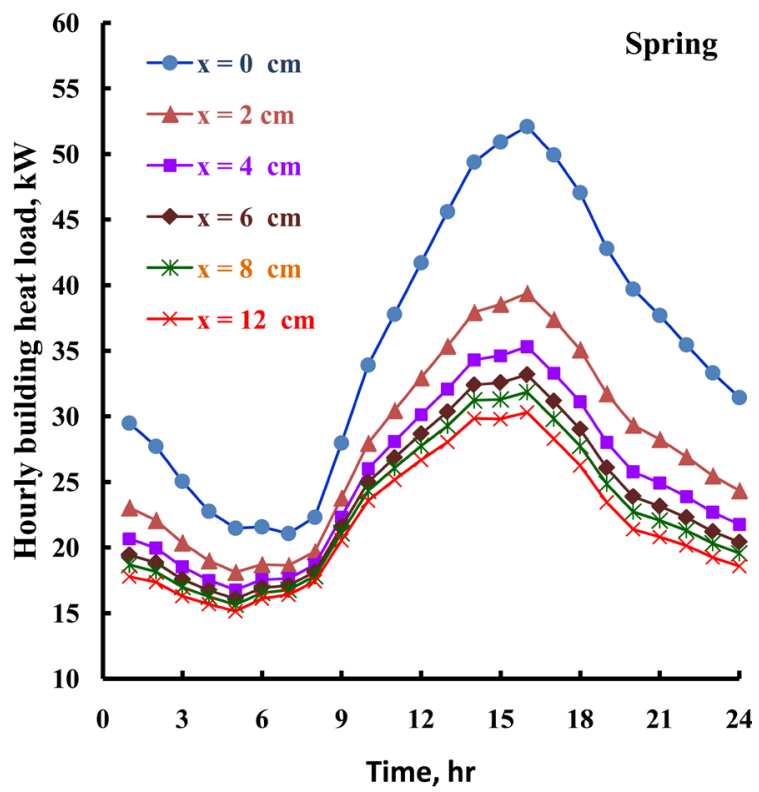

Figure 5. Building heat load in spring.

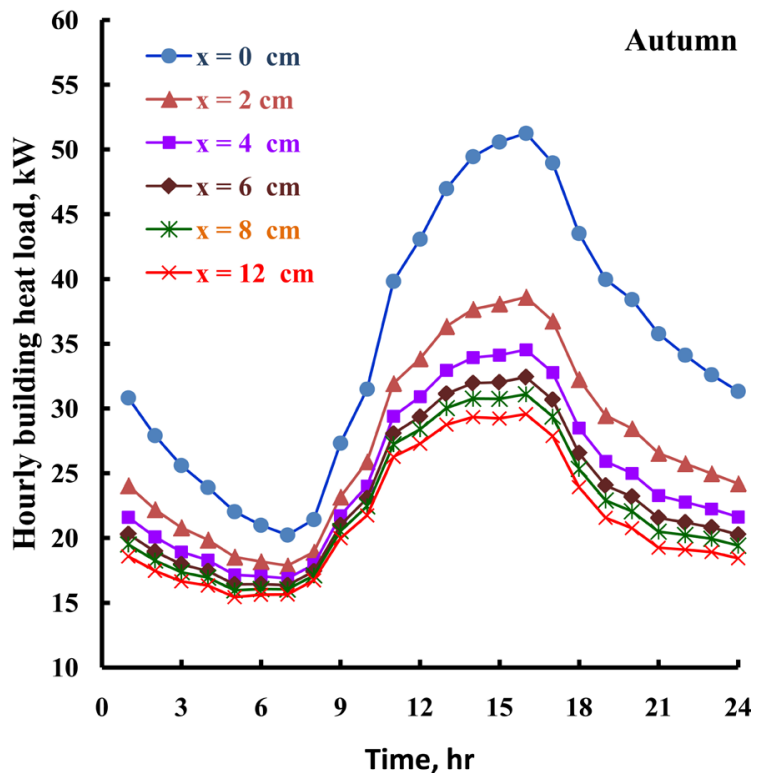

Figure 6. Building heat load in autumn.

insulation thickness, $\Delta x$, on the building heat load. Obviously, the building heat loads decrease with increasing thermal insulation thickness until $6-8 \mathrm{~cm}$. Also, the trends of hourly building heat loads in four season are similar to the trends of outside air temperature as shown in Figure 2 and the maximum heat loads occurred at 3:00 PM. Otherwise, when thermal insulation thickness increased to $8 \mathrm{~cm}$ and above, the building heat loads did not decrease by considerable value.

\section{Energy Consumption}

A compression refrigeration machine with air cooled condenser is considered. A 
Simple refrigeration cycle with DX evaporator of R134a was assumed at constant evaporating temperature of $8^{\circ} \mathrm{C}$ and condensing temperature of 10 degrees above outside air temperature. The assumed isentropic compression efficiency is $70 \%$ and pressure drop of $0.5 \mathrm{bar}$ in suction and delivery lines. The un-useful superheating is $1^{\circ} \mathrm{C}$ in suction line and sub-cooled is $5^{\circ} \mathrm{C}$ in liquid line. Cool Packprogram [25] is used in the analysis of refrigeration cycle to estimate the coefficient of performance, $C O P$, and compressor consumed power. The hourly coefficients of performance through four season are illustrated in Figure 8.

It is clear that from Figure 8, the hourly coefficient of performance in summer is low than other season, because the outside weather is very hot, but in winter is larger than other season. The hourly compressor consumed power of the refrigeration machine is calculated at various outside air temperature and thermal insulation thickness, $\Delta x$, of $0-12 \mathrm{~cm}$ and the results are shown in

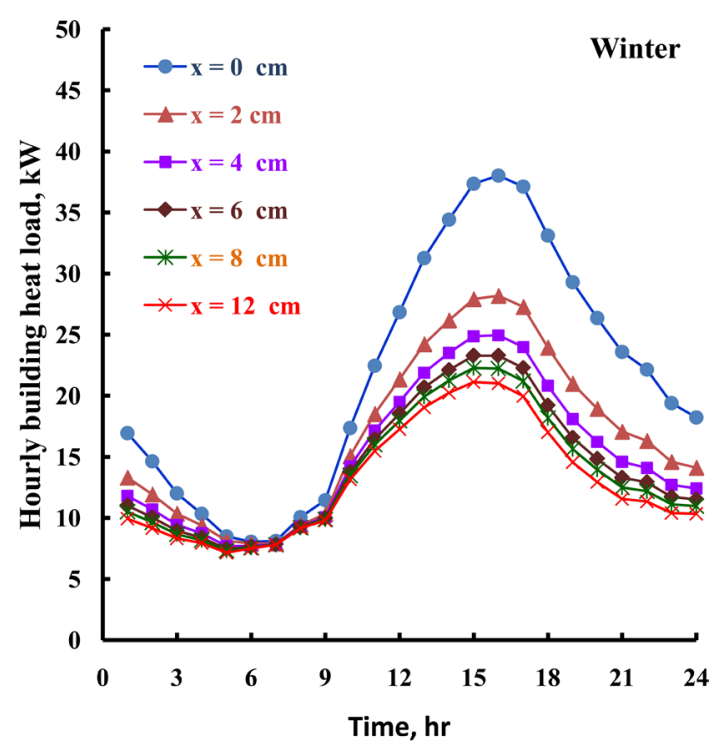

Figure 7. Building heat load in winter.

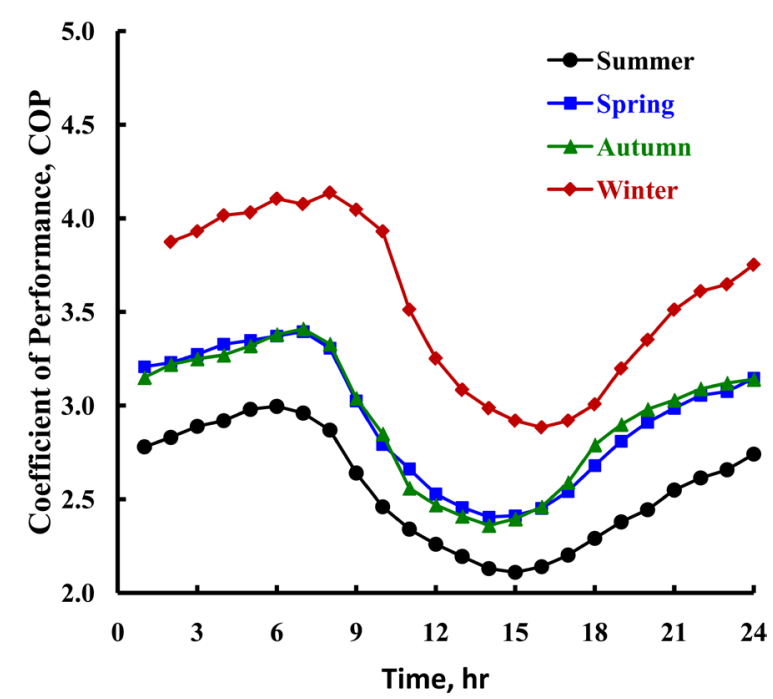

Figure 8. Coefficient of performance for refrigeration cycle. 
Figures 9-12. We can see a clear effect of thermal insulation thickness, $\Delta x$, on the compressor consumed power, and it decreased with increasing the thermal insulation thickness until $6-8 \mathrm{~cm}$. Also, with increasing thermal insulation thickness up to $8 \mathrm{~cm}$, the decrease in compressor power consumption is very small.

\section{Energy Saving}

The saving percentage in building heat load or compressor consumed power are calculated as the difference between the value without insulation and with insulation to the value without insulation as,

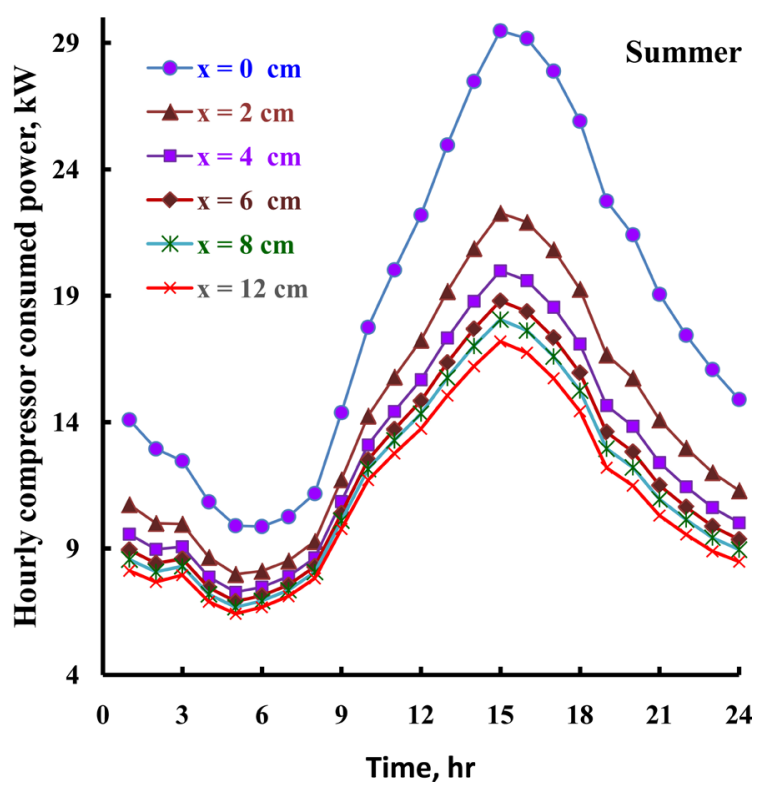

Figure 9. Compressor consumed power in summer.

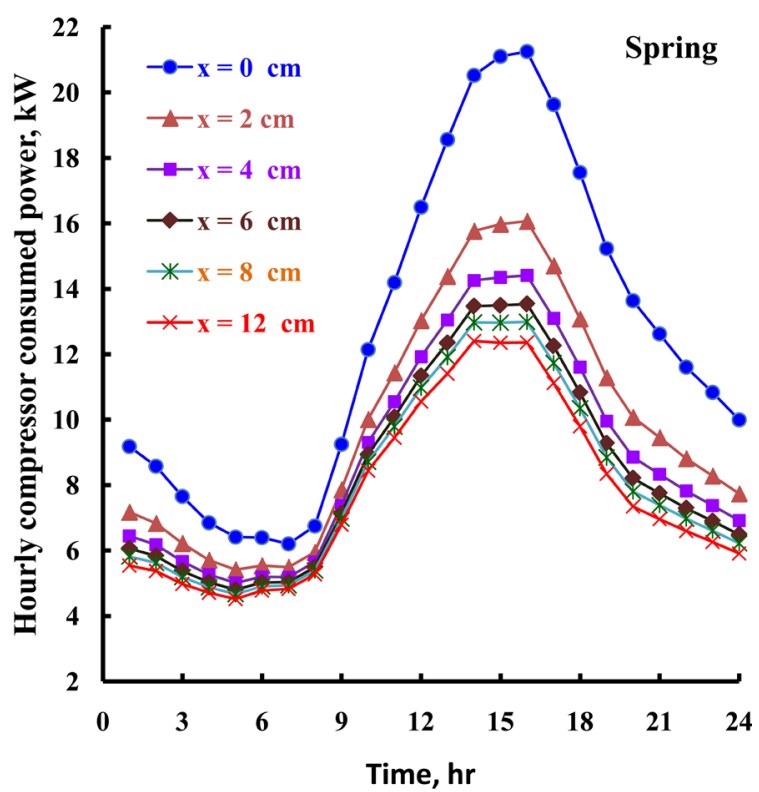

Figure 10. Compressor consumed power in spring. 


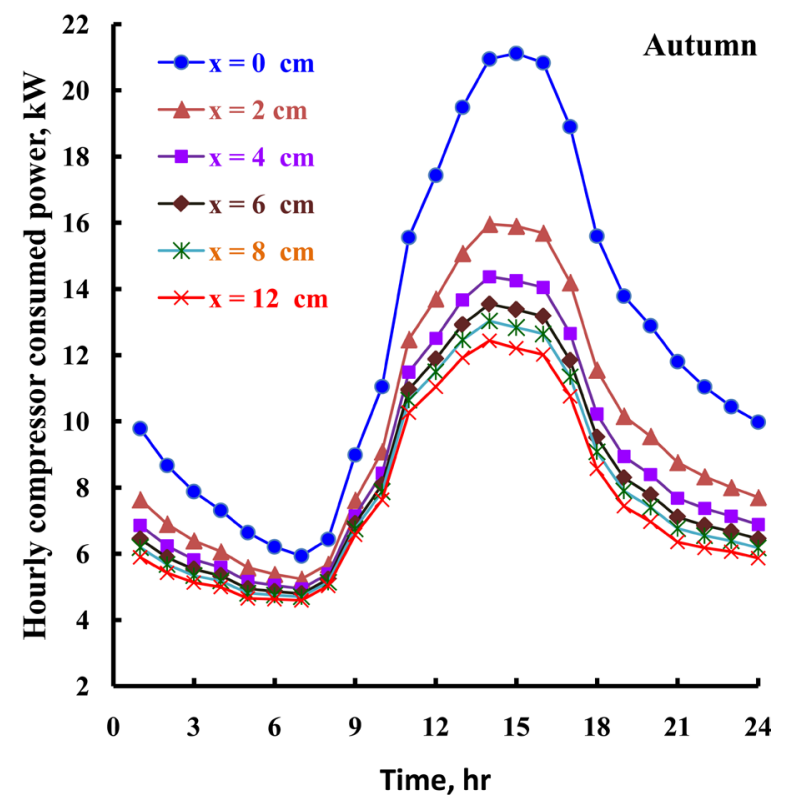

Figure 11. Compressor consumed power in autumn.

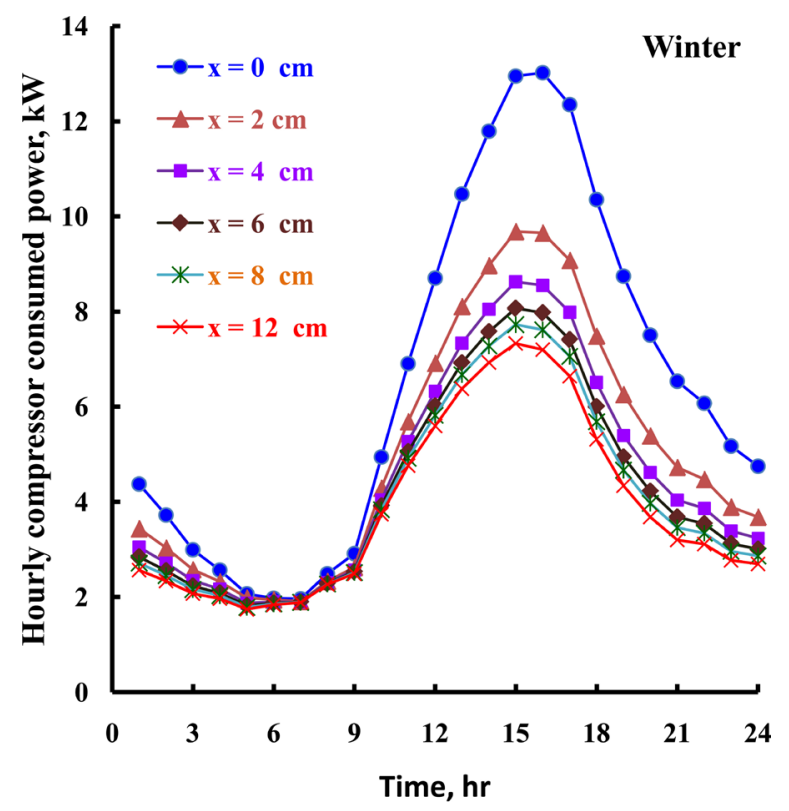

Figure 12. Compressor consumed power in winter.

$$
\text { Energy Saving }=\frac{\text { Value without insulation }- \text { Value with insulation }}{\text { Value without insulation }}
$$

Because the ratio between building heat load and the compressor consumed power is the coefficient of performance, the saving percentage of building heat load or compressor consumed power is the same value and trend. So, Figures 13-16 show the hourly saving percentage of compressor consumed powers in four seasons.

It is clear that from Figures 13-16, the hourly saving percentage increases from 9:00 AM to 8:00 PM of maximum value, and it decreases again. Also, the 
maximum saving percentage of consumed power is about $45 \%$ in summer, spring and autumn, but it attained to maximum value of $50 \%$ in winter.

Figure 17 shows the average daily saving percentage of compressor consumed power as a function of thermal insulation thickness in four season. The average daily saving increases with increasing the thermal insulation thickness until 6 $10 \mathrm{~cm}$. A small increase in the daily saving is found above $10 \mathrm{~cm}$ as shown in Figure 17. Figure 18 shows the average saving in compressor consumed power, and the average saving percentage in summer, spring, autumn and winter is $35.5 \%, 32.8 \%, 33.2 \%$ and $30.7 \%$ respectively. Also, the average saving percentage is about of $33 \%$ for all a year is illustrated in Figure 18 .

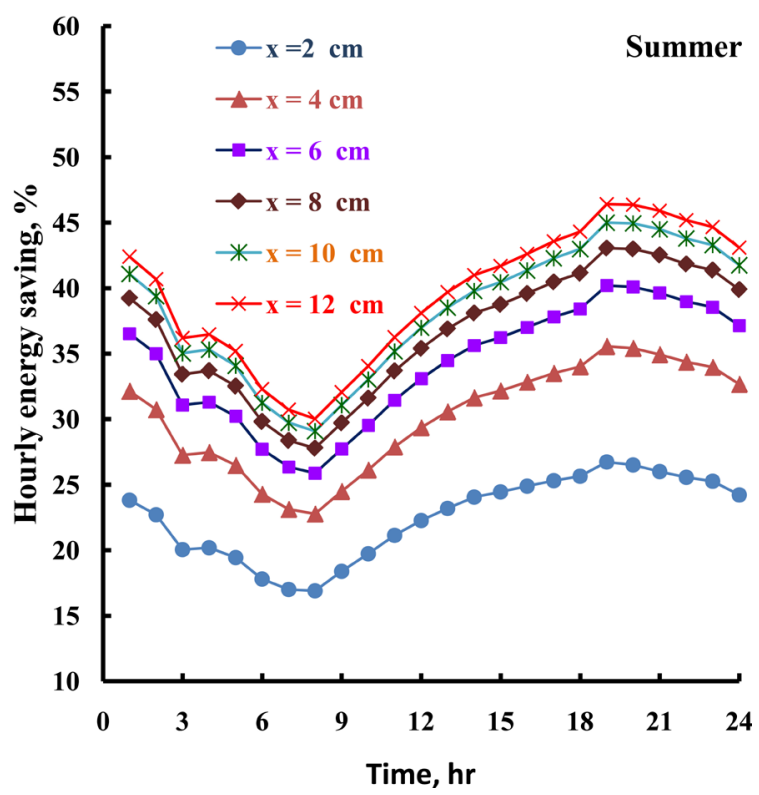

Figure 13. Hourly energy saving in summer.

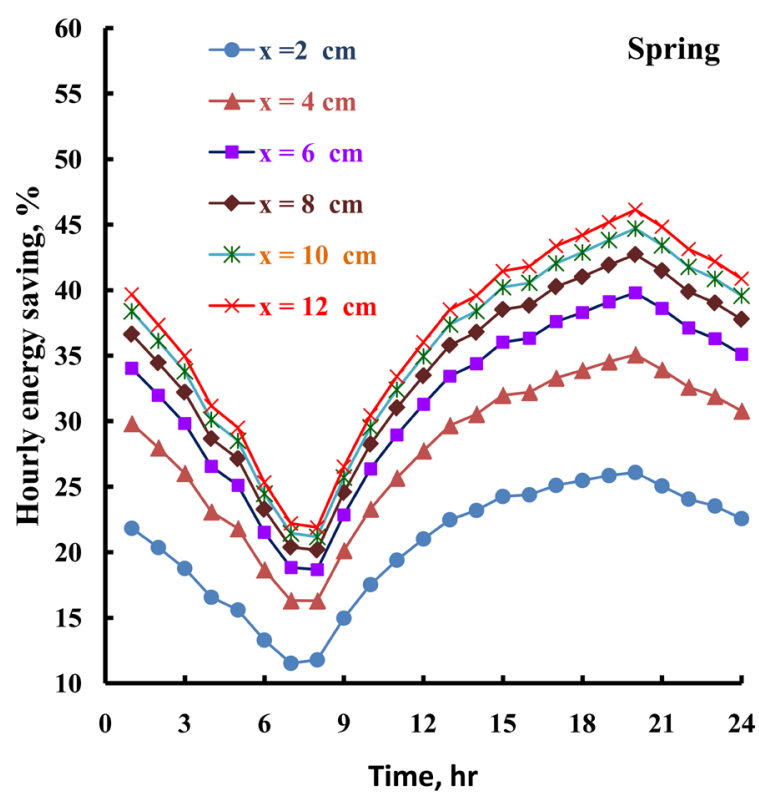

Figure 14. Hourly energy saving in spring. 


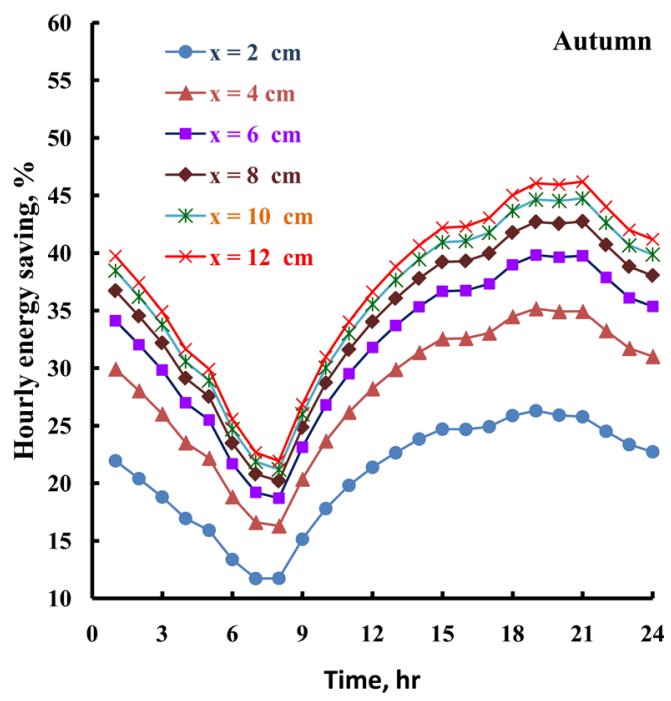

Figure 15. Hourly energy saving in autumn.

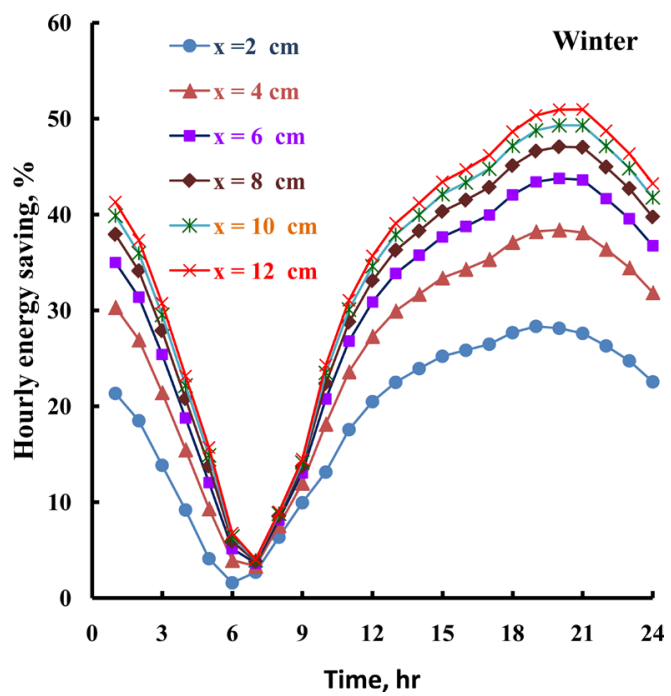

Figure 16. Hourly energy saving in winter.

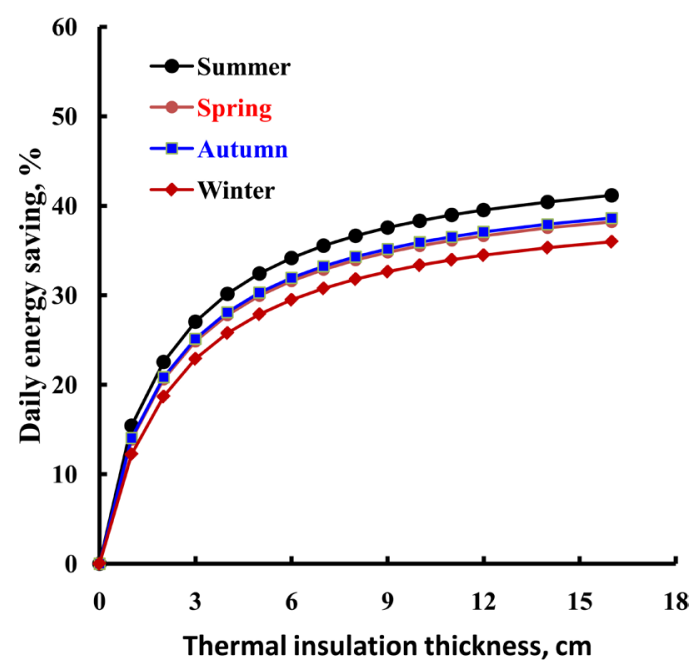

Figure 17. Average daily energy saving. 


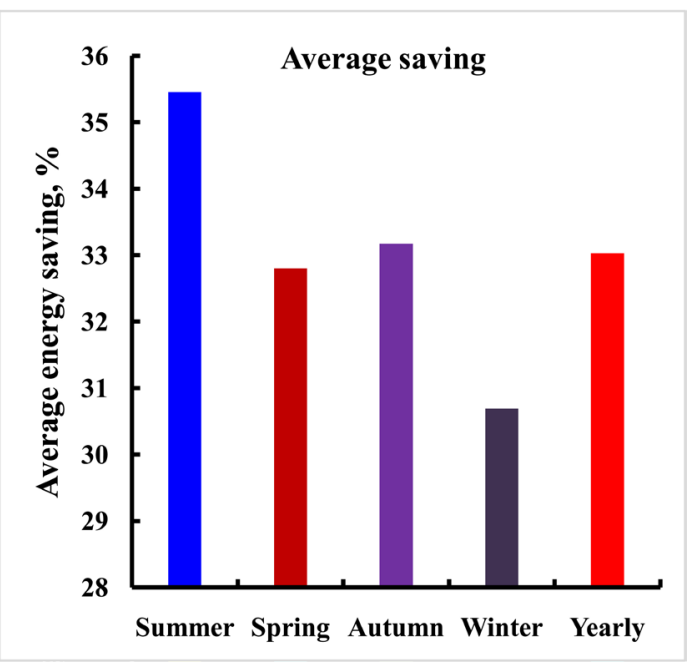

Figure 18. Seasonal and yearly average energy saving.

\section{Economic Analysis}

\subsection{Optimum Insulation Thickness and Payback Period}

It is important to determine the insulation thickness that minimizes the total cost, $C_{t}$, which is the cost of energy consumed plus the insulation cost [10] [11] as,

$$
C_{t}=C_{e n r} P W F+C_{i n s} \Delta x_{i n s}
$$

where, $C_{e n r}, \$ /\left(\mathrm{m}^{2} \cdot\right.$ year $)$ is the yearly cost of the electric energy consumed relative to the thermal gains through one square meter of wall. $P W F$, is the present worth factor. $C_{e n r}, \$ /\left(\mathrm{m}^{2} \cdot\right.$ year $)$ is the cost of one cubic meter of insulation, and $\Delta x_{i n s},(\mathrm{~m})$ is the thermal insulation thickness. Energy cost, $C_{e n r}$, is depending on the yearly thermal gains through the outer surface walls, $q_{T},\left(\mathrm{~W} / \mathrm{m}^{2}\right)$. Electrical cost, $C_{e l},(\$ / \mathrm{kWh})$ is the price of consumed energy and $C O P$ is the coefficient of performance of the refrigeration cycle for air-conditioning system as,

$$
C_{e n r}=\frac{q_{T} C_{e l}}{C O P}
$$

The yearly transmission load per unit of wall area is estimated in $\left(\mathrm{J} / \mathrm{m}^{2}\right)$ by the following equation,

$$
q_{T}=24 / 1000 U C D D=0.024 U C D D
$$

where, $U$ as Equation (6) and $C D D$ is the annual cooling degree-days which is defined as,

$$
C D D=\sum_{1}^{365}\left(T_{o}-T_{b}\right)
$$

where, $T_{o}$ is the outside temperature and $T_{b}$ is the base temperature which is equal to the inside conditioned building temperature which is $24^{\circ} \mathrm{C}$. The data of the annual cooling degree-days, $C D D$, are picked up from the National Climatic Data Center, meteorological stations of weather data of Egypt [27]. The effect of 
solar radiation and the hourly change of outside temperature are included in Equation (13) from Equation (5), and the annual cooling degree-days are modified as,

$$
C D D_{\bmod }=\sum_{1}^{365}\left((C L T D+L M) K-3.9+\left(T_{o}-T_{b}\right)\right)
$$

We used the absolute difference of $\left(T_{o}-T_{b}\right)$ to treat the cooling case in summer and heating case in winter. The annual energy cost for unit wall surface area can be rewritten as,

$$
C_{e n r}=\frac{0.024 C D D_{\text {mod }} C_{e l}}{\left(R_{w t}+(\Delta x / k)_{\text {ins }}\right) C O P}
$$

where, $R_{w t}$ is the total composite wall thermal resistance except insulation thermal resistance. The lifecycle total cost, $C_{t}$ is the energy cost and insulation cost can be rewrite as,

$$
C_{t}=\frac{0.024 C D D_{\text {mod }}}{C O P} \frac{1}{R_{w t}+(\Delta x / k)_{\text {ins }}} C_{e l} P W F+C_{\text {ins }} \Delta x_{\text {ins }}
$$

The optimal insulation thickness, $\Delta x_{o p t}$, is the thickness of the insulation layer that corresponds to that minimizing the total cost as,

$$
\Delta x_{\text {opt }}=\left(0.024 \frac{C D D_{\text {mod }} k_{\text {ins }} C_{e l} P W F}{C_{\text {ins }} C O P}\right)^{0.5}-k_{\text {ins }} R_{\text {wt }}
$$

The lifecycle saving, LCS, is the difference between the saved energy cost over the lifetime and the insulation cost [10] as,

$$
L C S=P W F \Delta E_{C}-C_{i n s} \Delta x_{i n s}
$$

where, $\Delta E_{C}$ the saved energy which is the difference between the annual energy consumption per unit area of the wall without and with insulation under cooling condition as,

$$
\Delta E_{C}=\frac{0.024 C D D_{\text {mod }} C_{e l}}{C O P}\left(\frac{1}{R_{w t}}-\frac{1}{R_{w t}+(\Delta x / k)_{\text {ins }}}\right)
$$

And the present worth factor $P W F$ is defined as,

$$
P W F= \begin{cases}\frac{1+i}{d-i}\left[1-\left(\frac{1+i}{1+d}\right)^{n}\right] & \text { at } i \neq d \\ \frac{n}{1+i} & \text { at } i=d\end{cases}
$$

The payback period $N_{P}$ (years) can be obtained by setting $L C S$ to be zero as,

$$
N_{P}= \begin{cases}\frac{\ln \left[1-\frac{C_{\text {ins }} \Delta x_{\text {ins }}}{\Delta E_{C}} \frac{d-i}{1+i}\right]}{\ln \left(\frac{1+i}{1+d}\right)} & \text { at } i \neq d \\ \frac{C_{\text {ins }} \Delta x_{\text {inc }}(1+i)}{\Delta E_{C}} & \text { at } i=d\end{cases}
$$

where, $n$ is the yearly lifecycle, $i$ is the currency inflation rate and $d$ is the in- 
terest rate. The parameters used in the calculation of the total cost, the optimum insulating thickness and payback period are given in Table 1.

Two main parameters are affecting the optimal thermal insulation thickness, the running cost of electrical energy and the investment cost of the thermal insulation volume. The tariff of electrical energy of $0.087 \$ / \mathrm{kWh}$ and expanded polystyrene thermal insulation cost of $53 \$ / \mathrm{m}^{3}$ are used in this analysis. The optimal thickness of thermal insulation and payback period is calculated in two cases. The first case is neglecting the effect of solar radiation on the outer walls surfaces and ceiling, and he cooling degree-days $C D D$ as Equation (13). The second case is taking into account the effect of solar radiation. The modified cooling degree-days, $C D D_{\text {mod }}$ as Equation (14) is used only through the day time from sunrise to sunset. But from sunset to sunrise, the $C D D$ is calculated by Equation (13) as the absolute value between outside and inside temperature of $\left(T_{o}-T_{b}\right)$ to treat the cooling and heating cases.

\subsection{Solar Radiation Effect on Total Cost}

Without exposed the outer walls surfaces to direct solar radiation, Figure 19 shows

Table 1. Parameters used in calculation.

\begin{tabular}{ccc}
\hline Parameters & Present data & Reference [26] \\
\hline$C_{e l}(\$ / \mathrm{kWh})$ & 0.087 & 0.1102 \\
$C_{\text {ins }}\left(\$ / \mathrm{m}^{3}\right)$ & 53 & 53 \\
$C O P$ & 3.0 & - \\
$R_{w t}\left(\mathrm{~m}^{2} \cdot \mathrm{K} / \mathrm{W}\right)$ & 0.5139 & 0.774 \\
Inflation rate, $i$ & $1 \%$ & $8.53 \%$ \\
Interest rate, $d$ & $5 \%$ & $9 \%$ \\
Cycle life time, $n$ & 10 years & 15 \\
$P W F$ & 8.127 & 8.58 \\
\hline
\end{tabular}

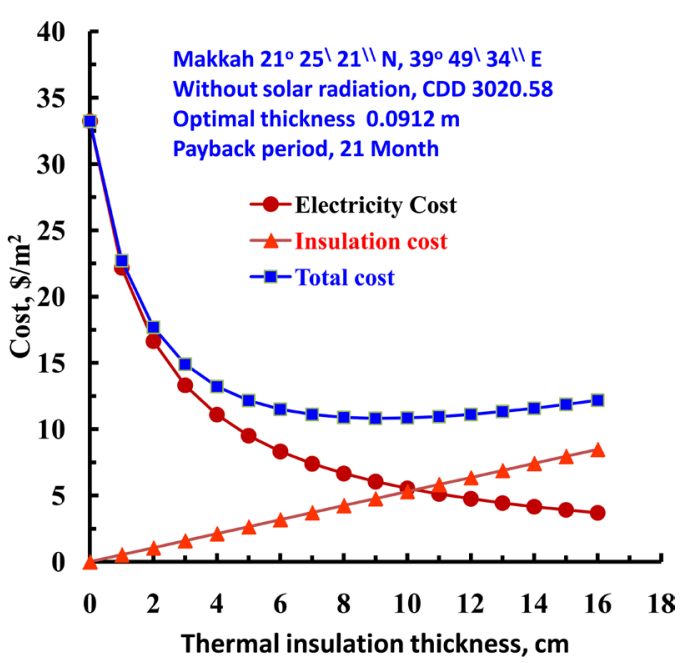

Figure 19. Optimal thermal insulation thickness, without solar radiation. 
the energy cost, thermal insulation cost and total cost as a function of insulation thickness. The running cost of electrical energy is decreased with increasing the thermal insulation thickness, but the cost of thermal insulation increases with increasing the insulation thickness. The thermal insulation thickness is increased gradually from 0 to $16 \mathrm{~cm}$. The total cost is gradually decreasing to a minimum value and increased again. At this point the optimum value of insulation thickness is appointed and it is obtained of $9.12 \mathrm{~cm}$ and payback period is 19 months. According to the previous studies [10] [11], similar results are illustrated and the optimal thickness of extruded polystyrene (XPS) was between 5.3 and $6.9 \mathrm{~cm}$ and expanded polystyrene (EPS) was between 8.1 and $10.5 \mathrm{~cm}$. The payback period varies from 22 to 30 months.

With including the effect of solar radiation on the outer walls surfaces, the modified annual cooling degree-days, $C D D_{\text {mod }}$ was calculated from Equation (14). The values of correction factor, $L M$, and the Cooling Load Temperature Difference, $C L T D$, are illustrated in Table 2. The values of $L M$ in a certain month at

Table 2. Latitude correction factor, $L M[22]$.

\begin{tabular}{|c|c|c|c|c|c|}
\hline Latitude & Months & North & East/West & South & Horizontal \\
\hline \multirow{7}{*}{$16^{\circ}$} & December & -2.2 & -2.2 & 7.2 & -5.0 \\
\hline & January/November & -2.2 & -2.2 & 6.6 & -3.8 \\
\hline & February/October & -1.6 & -1.1 & 3.8 & -2.2 \\
\hline & March/September & -1.6 & -0.5 & 0.0 & -0.5 \\
\hline & April/August & -0.5 & -0.5 & -3.2 & 0.0 \\
\hline & May/July & 2.2 & -0.5 & -3.8 & 0.0 \\
\hline & June & 3.3 & -0.5 & -3.8 & 0.0 \\
\hline \multirow{7}{*}{$24^{\circ}$} & December & -2.7 & -3.8 & 7.2 & -7.2 \\
\hline & January/November & -2.2 & -3.3 & 7.2 & -6.1 \\
\hline & February/October & -2.2 & -1.6 & 5.5 & -3.8 \\
\hline & March/September & -1.6 & -0.5 & 2.2 & -1.6 \\
\hline & April/August & -1.1 & -0.5 & -1.6 & 0.0 \\
\hline & May/July & 0.5 & 0.0 & -3.3 & 0.5 \\
\hline & June & 1.6 & 0.0 & -3.2 & 0.5 \\
\hline \multirow{7}{*}{$32^{\circ}$} & December & -2.7 & -4.4 & 6.6 & -9.4 \\
\hline & January/November & -2.7 & -4.4 & 6.6 & -8.3 \\
\hline & February/October & -2.2 & -2.2 & 6.1 & -5.5 \\
\hline & March/September & -1.6 & -1.1 & 3.8 & -2.7 \\
\hline & April/August & -1.1 & 0.0 & 0.5 & -0.5 \\
\hline & May/July & 0.5 & 0.0 & -1.6 & 5.0 \\
\hline & June & 0.5 & 0.0 & -2.6 & 1.1 \\
\hline
\end{tabular}

The average value of $C L T D$ for ceiling $16.38^{\circ} \mathrm{C}$, for walls, North $6.54^{\circ} \mathrm{C}$, East/West $12^{\circ} \mathrm{C}$, South $9.33^{\circ} \mathrm{C}$. The middle color factor, $k=0.65$. 
wall orientation are calculated by interpolation at a given latitude.

Figure 20 shows the effect of solar radiation on energy consumption, insulation thickness and total cost of walls and ceiling. The thermal insulation thickness is illustrated from $0-16 \mathrm{~cm}$ and the optimal insulation thickness for walls is obtained of $10.06 \mathrm{~cm}$ and for ceiling is $11.68 \mathrm{~cm}$. The payback period is found of 18 - 20 months. When we used the average value of $C D D_{\text {mod }}$ for walls and ceiling, the optimal insulation thickness is obtained of $10.89 \mathrm{~cm}$ and payback periods of 19 months. We observed that the walls optimum thermal insulation thickness with the effect of solar radiation is increased by $10.31 \%$ than walls without solar radiation effect.

It is important to calculate the optimal thermal insulation thickness and payback periods with the effect of solar radiation for some cities in Egypt. So, we used the same procedures for some important cities in Egypt from latitude of $24^{\circ} \mathrm{N}$ to $32^{\circ} \mathrm{N}$ and the results are illustrated in Table 3 . Figure 21 shows the effect of annual degree-days on the optimum insulation thicknesses and payback period for the present data. Obviously, the present data for both walls and ceiling shows the optimum thermal insulation thickness is increased from 7.12 -

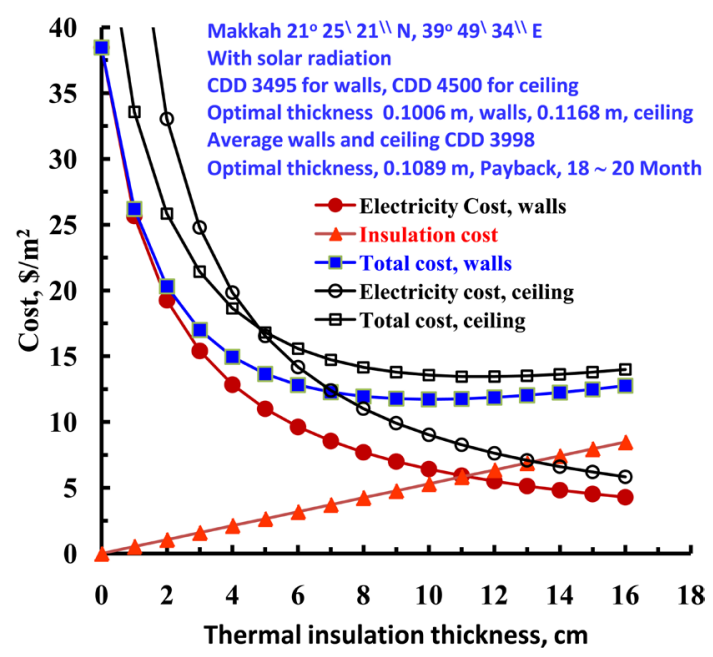

Figure 20. Optimal thermal insulation thickness, with solar radiation.

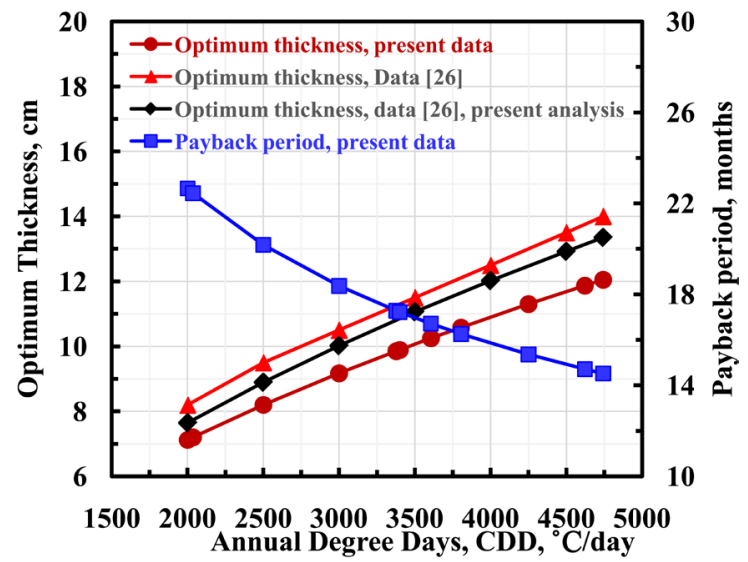

Figure 21. Effect of annual degree days on optimum insulation thickness. 
$12.05 \mathrm{~cm}$ with increasing the annual degree-days. Because of the roof is treated as a horizontal slab without suspended ceiling and the $C L T D$ larger than walls. So, the optimum insulation thickness for ceiling is larger than walls by about $20.19 \%$. Also, the payback period is decreased with increasing the optimum insulation thickness as shown in Figure 21 and it decreased from 23 months to 15 months.

The optimum insulation thickness of data which sited in reference [26] is calculated by our analysis with parameters from Table 1 and compared with sited data. The estimated result of optimum insulation thickness by our analysis is a little lower than the sited data by about $4.9 \%$. Also, it is observed that the sited data in reference [26] is larger than our data by about of $12.76 \%$ at the same degree-days, maybe due to the different values of electrical energy cost.

\subsection{Effect of Insulation Materials on Optimum Thickness}

To investigate the effect of insulation materials on the optimum thickness periods, five types of thermal insulation materials are used and its properties are illustrated in Table 4. Figure 22 shows the optimum insulation thickness for various insulation materials with annual degree-days. The optimum insulation thickness increases with increasing thermal conductivity of the insulation materials as Extruded polystyrene (XPS), Expanded polystyrene (EPS), and Glass wool (GW). Also, the optimum insulation thickness depends on the price of the

Table 3. Optimum insulation thickness for some cities in Egypt.

\begin{tabular}{cccccc}
\hline City & $\begin{array}{c}\text { Location } \\
\text { Latit./Longit. }\end{array}$ & Object & $\begin{array}{c}C D D_{\text {mod }} \\
\text { Degree-days }\end{array}$ & $\begin{array}{c}\Delta \boldsymbol{x}_{\text {opt }} \\
(\mathrm{cm})\end{array}$ & $\begin{array}{c}\text { Payback } \\
\text { years }\end{array}$ \\
\hline Alexandria & $31^{\circ} 12^{\prime} 20^{\prime \prime} \mathrm{N}$ & Walls & 2000 & 7.12 & 1.888 \\
& $29^{\circ} 55^{\prime} 28^{\prime \prime} \mathrm{E}$ & Ceiling & 3378 & 9.85 & 1.44 \\
Cairo & $30^{\circ} 01^{\prime} 59^{\prime \prime} \mathrm{N}$ & Walls & 2035 & 7.2 & 1.871 \\
& $31^{\circ} 14^{\prime} 00^{\prime \prime} \mathrm{E}$ & Ceiling & 3400 & 9.89 & 1.435 \\
Assiut & $27^{\circ} 11^{\prime} 00^{\prime \prime} \mathrm{N}$ & Walls & 3805 & 10.58 & 1.355 \\
& $31^{\circ} 10^{\prime} 00^{\prime \prime} \mathrm{E}$ & Ceiling & 4743 & 12.05 & 1.210 \\
& $24^{\circ} 05^{\prime} 20^{\prime \prime} \mathrm{N}$ & Walls & 3606 & 10.25 & 1.393 \\
\hline \multirow{2}{*}{ Aswan } & $32^{\circ} 53^{\prime} 59^{\prime \prime} \mathrm{E}$ & Ceiling & 4622 & 11.87 & 1.226 \\
\hline
\end{tabular}

Table 4. Properties of insulation materials [26].

\begin{tabular}{ccc}
\hline Insulation materials & $\boldsymbol{k}(\mathrm{W} / \mathrm{m} \cdot \mathrm{K})$ & Cost $\left(\$ / \mathrm{m}^{3}\right)$ \\
\hline Extruded polystyrene (XPS) & 0.031 & 79 \\
Expanded polystyrene (EPS) & 0.039 & 53 \\
Glass wool (GW) & 0.04 & 27 \\
Polyurethane (PUR) & 0.024 & 118 \\
Polyisocyanurate (PIR) & 0.023 & 105 \\
\hline
\end{tabular}




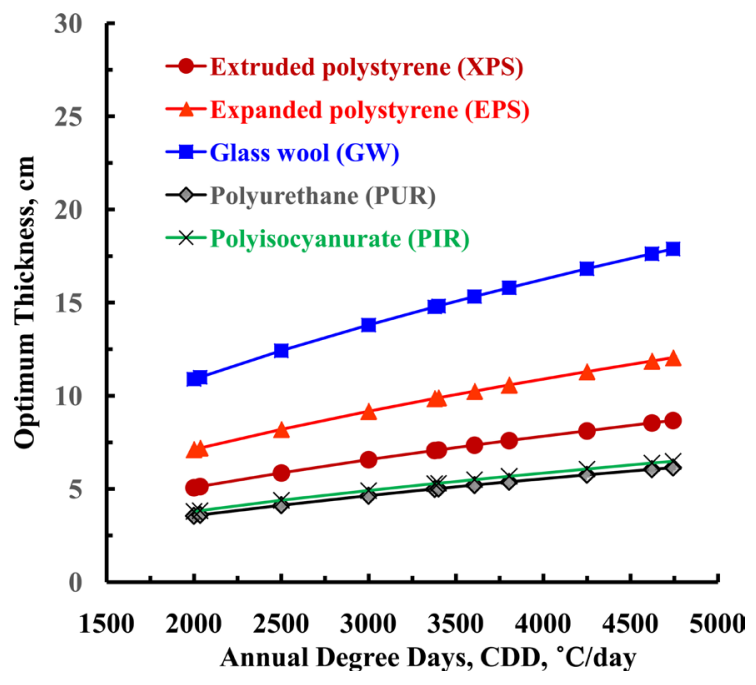

Figure 22. Effect of insulation materials on optimum insulation thickness.

insulation material, and it decreases as the price of the insulation materials increased at the same thermal conductivity, Polyurethane (PUR) and Polyisocyanurate (PIR).

\section{Conclusion}

The building heat load and energy consumption by air conditioning system are proportional to the environmental conditions and solar radiation intensity. The building heat load was estimated for two models of walls. The walls models are constructed from common materials with $0-16 \mathrm{~cm}$ of thermal insulation thickness in the outer walls and ceilings, and double-layers glazing windows. The optimal thermal insulation thickness and payback period are estimated for residential building from latitude of $16^{\circ} \mathrm{N}$ to $32^{\circ} \mathrm{N}$. The average saving percentages in energy consumption in summer, spring, autumn and winter are estimated as, $35.5 \%, 32.8 \%, 33.2 \%$ and $30.7 \%$ respectively. But the yearly average saving percentage is about of $33.5 \%$. Economic analysis is conducted with the annual cooling degree-days and life cycle total cost to estimate the optimum thickness and payback periods. The optimal thermal insulation thickness for some Egyptian cities is found between $7-12 \mathrm{~cm}$ for various annual cooling degree-days of 2000 to 5000 and five types of insulation materials. Without including the effect of solar radiation, the optimum insulation thickness of ceiling is larger than walls by about $20 \%$. But with including the effect of solar radiation, the optimal thermal insulation thickness for walls is about $10 \mathrm{~cm}$ and ceiling of $11.68 \mathrm{~cm}$, and payback period is found between 15 - 24 months.

\section{Conflicts of Interest}

The author declares no conflicts of interest regarding the publication of this paper.

\section{References}

[1] Satman, A. and Yalcinkaya, N. (1999) Heating and Cooling Degree-Hours for Tur- 
key. Energy, 24, 833-840. https://doi.org/10.1016/S0360-5442(99)00035-3

[2] Durmayaz, A., Kadioglu, M. and Sen, Z. (2000) An Application of the Degree-Hours Method to Estimate the Residential Heating Energy Requirement and Fuel Consumption in Istanbul. Energy, 25, 1245-1256.

https://doi.org/10.1016/S0360-5442(00)00040-2

[3] Buyukalaca, O., Bulut, H. and Yilmaz, T. (2001) Analysis of Variable-Base Heating and Cooling Degree-Days for Turkey. Applied Energy, 69, 269-283. https://doi.org/10.1016/S0306-2619(01)00017-4

[4] Zedan, M.F. and Mujahid, A.M. (1993) An Efficient Solution for Heat Transfers in Composite Walls with Periodic Ambient Temperature and Solar Radiation. International Journal of Ambient Energy, 4, 83-98. https://doi.org/10.1080/01430750.1993.9675599

[5] Hasan, A. (1999) Optimizing Insulation Thickness for Buildings Using Life Cycle Cost. Applied Energy, 63, 115-124. https://doi.org/10.1016/S0306-2619(99)00023-9

[6] Granja, A.D. and Labaki, L.C. (2003) Influence of External Surface Color on the Periodic Heat Flow through a Flat Solid Roof with Variable Thermal Resistance. International Journal of Energy Research, 27, 771-779. https://doi.org/10.1002/er.915

[7] Mahalia, T.M.I., et al. (2007) Correlation between Thermal Conductivity and the Thickness of Selected Insulation Materials for Building Wall. Energy and Buildings, 39, 182-187. https://doi.org/10.1016/j.enbuild.2006.06.002

[8] Daouas, N., Hassen, Z. and Ben Aissia, H. (2010) Analytical Periodic Solution for the Study of Thermal Performance and Optimum Insulation Thickness of Building Walls in Tunisia. Applied Thermal Engineering, 30, 319-326. https://doi.org/10.1016/j.applthermaleng.2009.09.009

[9] Nyers, J. (2014) Economic Optimum of Thermal Insulating Layer for External Wall of Brick. Acta Polytechnica Hungarica, 11, 209-222. https://doi.org/10.12700/APH.11.07.2014.07.13

[10] Liu, X., et al. (2015) Determination of Optimum Insulation Thickness of Exterior Wall with Moisture Transfer in Hot Summer and Cold Winter Zone of China. Procedia Engineering, 121, 1008-1015. https://doi.org/10.1016/j.proeng.2015.09.072

[11] Modeste, K.N., et al. (2017) A Comparative Study on Optimum Insulation Thickness of Walls and Energy Savings in Equatorial and Tropical Climate. International Journal of Sustainable Built Environment, 6, 170-182. https://doi.org/10.1016/j.ijsbe.2017.02.001

[12] Asadi, I., et al. (2019) Determination of Optimum Insulation and Cement Plaster Thickness for Bungalow Buildings through a Simulation-Statistical Approach Using Response Surface Methodology. Journal of Design and Built Environment, 19, 48-63.

[13] Kaynakli (2011) Parametric Investigation of Optimum Thermal Insulation Thickness for External Walls. Energies, 4, 913-927. https://doi.org/10.3390/en4060913

[14] Jafri, S.A.H., et al. (2018) Analyzing Optimum Thickness for Combination of Two Thermal Insulation Materials for Building Walls. IOP Conference Series Materials Science and Engineering, 404, Article ID: 012050. https://doi.org/10.1088/1757-899X/404/1/012050

[15] Abdelgadir, E.K.M., et al. (2019) Optimum Insulation Thickness for Building under Different Climate Region-A Review. Journal of Advanced Research in Fluid Mechanics and Thermal Sciences, 59, 254-268.

[16] Dombayci, O.A., et al. (2020) Determination of Optimum Insulation Thickness for Building External Walls with Different Insulation Materials Using Environmental 
Impact Assessment. Thermal Science, 24, 303-311.

https://doi.org/10.2298/TSCI180903010D

[17] Paya-Marin, M.A., et al. (2020) Large-Scale Experiment of a Novel Non-Domestic Building Using BPSC Systems for Energy Saving. Renewable Energy, 152, 799-811. https://doi.org/10.1016/j.renene.2020.01.100

[18] Wang, Y., et al. (2020) Optimum Insulation Thickness for the Sandwich Structure Livestock Buildings External Envelopes in Different Climate Regions of China. International Journal of Agricultural and Biological Engineering, 13, 29-41. https://doi.org/10.25165/j.ijabe.20201301.5280

[19] Necib, H. and Necib, B. (2020) Improve the Calculation Accuracy of the Optimal Insulation Thickness in Building Walls as Determined by a Dynamic Heat Transfer Model. Asian Journal of Civil Engineering, 21, 903-913.

https://doi.org/10.1007/s42107-020-00248-w

[20] Mohamed, M.M. and Almarshadi, M.H. (2016) Simulation of District Cooling Plant and Efficient Energy. 1 st International Conference on New Trends for Sustainable Energy, Alexandria, 1-3 October 2016, 191-197.

[21] Mohamed, M.M. and Almarshadi, M.H. (2017) Simulation of District Cooling Plant and Efficient Energy Air Cooled Condensers (Part I). JECTC, 7, 45-62.

https://doi.org/10.4236/jectc.2017.73005

[22] (1997) ASHRAE Fundamentals Handbook. SI, Chapter 27.

[23] Moran, J. and Shapiro, N.M. (2010) Fundamentals of Engineering Thermodynamics. 7th Edition, John Wiley \& Sons, Hoboken.

[24] Cengel, Y.A. and Ghajar, A.J. (2015) Heat and Mass Transfer: Fundamentals and Applications. 5th Edition, McGraw-Hill, New York.

[25] Department of Mechanical Engineering, Technical University of Denmark. https://www.ipu.dk/products/coolpack/

[26] Aktemur, C. and Atikol, U. (2017) Optimum Insulation Thickness for the Exterior Walls of Buildings in Turkey Based on Different Materials, Energy Sources and Climate Regions. International Journal of Engineering Technologies, 3, 72-82. https://doi.org/10.19072/ijet.307239

[27] Photius Coutsoukis and Information Technology Associates. https://geographic.org/global_weather/egypt/index.html 


\section{Nomenclature}

$A$ : $\quad$ wall surface area $\left(\mathrm{m}^{2}\right)$

$C_{e i} \quad$ energy cost $(\$ / \mathrm{kWh})$

$C_{\text {ins: }}$ insulation cost $\left(\$ / \mathrm{m}^{3}\right)$

$C D D$ : cooling degree-day $\left({ }^{\circ} \mathrm{C} /\right.$ day $)$

$C L T D$ : cooling load temperature difference $(\mathrm{K})$

COP: coefficient of performance (-)

$h$ : $\quad$ heat transfer coefficient $\left(\mathrm{W} \cdot \mathrm{m}^{-2} \cdot \mathrm{K}^{-1}\right)$

$K: \quad$ color factor (-)

$k$ thermal conductivity $\left(\mathrm{W} \cdot \mathrm{m}^{-1} \cdot \mathrm{K}^{-1}\right)$

$L M: \quad$ latitude correction factor (-)

Q: $\quad$ heat transfer rate (W)

$R: \quad$ wall thermal resistance $\left(\mathrm{m}^{2} \cdot \mathrm{K} \cdot \mathrm{W}^{-1}\right)$

$T: \quad$ temperature $(\mathrm{K})$

t. $\quad$ time (s)

$x . \quad$ thickness (m)

$U: \quad$ overall heat transfer coefficient $\left(\mathrm{W} \cdot \mathrm{m}^{-2} \cdot \mathrm{K}^{-1}\right)$

\section{Subscript}

$\begin{array}{ll}\text { enr. } & \text { energy } \\ \text { el: } & \text { electrical } \\ o: & \text { outside } \\ \text { opt. } & \text { optimum } \\ i: & \text { inside } \\ \text { ins. } & \text { insulation } \\ \text { trans. } & \text { transmission } \\ w t . & \text { wall materials }\end{array}$

